\title{
Australian Journal of Crop Science \\ Tolerance of common bean (Phaseolus vulgaris L.) to different durations of simulated shallow water table condition
}

\author{
Benyamin Lakitan $^{1,2^{*}}$, Sabaruddin Kadir $^{3}$, Andi Wijaya ${ }^{1}$, Susilawati ${ }^{1}$ \\ ${ }^{1}$ College of Agriculture, Department of Agronomy, Universitas Sriwijaya, Inderalaya 30662, Indonesia \\ ${ }^{2}$ Research Center for Sub-optimal Lands (PUR-PLSO), Universitas Sriwijaya, Palembang 30139, Indonesia \\ ${ }^{3}$ College of Agriculture, Department of Soil Sciences, Universitas Sriwijaya, Inderalaya 30662, Indonesia
}

\section{*Corresponding author: blakitan60@unsri.ac.id}

\begin{abstract}
Shallow water table problem has lessened farmer's interest in cultivating vegetables at riparian wetland in Indonesia. At present, riparian wetlands are mostly underutilized. Objective of this study was to evaluate tolerance of common bean (Phaseolus vulgaris) to shallow water table condition. Common bean variety of PV072 was used in this study. Research was conducted in Jakabaring, South Sumatra, Indonesia; from November 2016 to February 2017. Leaf and root growth or damage can be used as an indicator of stress tolerance in plants exposed to unfavorable soil conditions. Results of our study indicated that roots of common bean were unable to survive in water saturated condition below water table, but the plants were able to compensate for this constraint by increasing root biomass within aerobic substrate above water table. Moreover, after termination of shallow water table treatment, common bean was able to regrow their roots into the ex-saturated zone. Common bean plants produced marketable yield albeit limited rhizosphere space. Interestingly, the plants exposed to 24 days of shallow water table produced the highest yield. In conclusion, common bean can be considered as tolerant vegetable to shallow water table. It should be noted that bean leaf reached 90 percent and full size in less than 6 days and 9 days, respectively, after the young leaf was unfolded. Therefore, long term study on bean leaf growth and development requires measurement on sequential and multiple leaves. Also, nocturnal relative leaf expansion rate (RLER) was significantly faster than diurnal RLER.
\end{abstract}

Keywords: Cropping intensity; excess water; hypoxia; leaf expansion rate; riparian wetland; root regrowth; stress recovery; tropical vegetable; sub-optimal land; waterlogging.

Abbreviations: DAP_days after planting; LSD_least significant difference; RLER_relative leaf expansion rate; WT_water table.

\section{Introduction}

Shallow water table horizontally splits rhizosphere into two layers, aerobic layer (above) and anaerobic layer (below) the water table. This dual-layer condition commonly occured at riparian wetland ecosystem. Only rice and few hydrophilic vegetables (such as Ipomoea aquatic and Limnocharis flava) have been proven to adapt well to this unfavorable soil condition. Common bean (Phaseolus vulgaris L.) has not been considered as a suitable vegetable crop for the wetland ecosystem.

Shallow water table can be regarded as partial waterlogging with well-aerated layer at upper zone and waterlogged or water-saturated layer at lower zone of rhizosphere. Presence of water-saturated layer below water table has been a major concern, not due to excessive water condition but due to oxygen shortage (hypoxia) or complete absence of oxygen (anoxia) in soil environment which restricts growth, development, and yield of susceptible crops (Hossain and Uddin, 2011). Roots are most prone to and the first to suffer from oxygen shortage in soil (Sauter, 2013), and the roots are severely damaged if continuous hypoxic conditions prevail. The hypoxic condition restricts root growth to only within aerobic layer above water level.
Some studies suggested that the top third of the root zone, where the root density was usually greatest, was the most important root zone (Soppe and Ayars, 2002). Hence, limited space for roots to expand generally decreased rootto-shoot ratio, causing suboptimal functioning of the roots; at the end, resulting in nutrient and water deficiencies at the shoots (Colmer and Greenway, 2011). Ashraf et al. (2011) found that excess water significantly reduced $\mathrm{N}, \mathrm{K}$, and $\mathrm{Ca}$ accumulation in stem, root and leaves. In contrast, concentration of $\mathrm{Mn}$ and Fe (potentially toxic elements at higher concentration) was generally increased.

Bajgain et al. (2015) found that soybeans exposed to shallow water table for two weeks at early vegetative stage produced lower yield, total dry weight, and total leaf area compared to those grown under a normal condition, where water table was far below root zone. Similar result was reported by Ashraf et al. (2011) that excess water significantly reduced plant height, fresh weight, dry weight, and photosynthetic pigments in cotton. Najeeb et al. (2016) also reported that excess water significantly reduced dry biomass, leaf $\mathrm{N}$ concentration and fruit development in cotton. 
Furthermore, excess water not only restricts growth but also causes damage to existing roots. Irfan et al. (2010) stated that oxygen deficiency (hypoxia) or its complete absence (anoxia) could damage the roots under transient or sustained excess water condition. Moreover, stagnant excess water for a longer period may cause lethal impact on susceptible crops.

Due to risks of shallow water table and other problems associated with excess water condition, cropping intensity and productivity at riparian wetlands have been considerably low, except for intensively managed rice fields. Increase in food demand (as a consequence of growing population) and limited availability of arable lands have inevitably driven the need for intensifying crop production at the riparian wetlands which are currently underutilized in Indonesia and in many other less developed countries.

Researches on riparian wetlands in Indonesia have been heavily focused on rice crop, whereas much less attention has been given to other food and horticultural crops. Government policy and incentives have been favoring rice growers. However, farmers cannot afford their decent livelihood by solely depending on rice cultivation. Diversifying crop grown at the wetland would increase cropping intensity and decrease dependability of local communities on purchased other food and horticultural crops. Local farmers should be encouraged to cultivate vegetables for fulfilling at least their own needs. The main objective of our research was to evaluate tolerability of common bean to shallow water table condition at duration up to 24 days during reproductive phase.

\section{Results}

\section{Leaf expansion as indicator of stress and its limitation}

Leaf of common bean required about 9 days to reach full size and reached 90 percent of its full size in less than 6 days after the leaf was unfolded (Fig 1). Regardless of difference in initial sizes at time of unfolding, the leaves reached their full size at about the same time. Asymptotical patterns of leaf growth indicated that the leaves were expanded faster during the first 4-5 days period, then the expansion rate was slowing down, and the leaf stopped to enlarge beyond 9 days after unfolding.

Relative leaf expansion rate was faster at night (nocturnal RLER) than during daytime (diurnal RLER) in common bean exposed to shallow water table (Fig. 2). Larger variability in nocturnal RLER suggested that ideal time to measure RLER was during night time for detecting stress symptom in plants exposed to unfavorable conditions. Differences in RLER among common bean plants exposed to shallow water table condition were more visible during the first 4-5 days of fast development.

Short term (up to 6 days) exposure to shallow water table did not significantly decline SPAD value; however, the SPAD value started to decline after 6 days exposure, and SPAD value was significantly lower than untreated control or any other treatments at 24 days of exposure (Fig 3).

\section{Root damage and recoverability}

If the roots were continuously exposed to water saturated soil, at a certain period of time depending on tolerant level of the plant, they started to experience the hypoxic condition and eventually damaged. However, it did not completely damage all submerged roots below water table $(13.5 \mathrm{~cm})$ of common bean exposed for 3 to 6 days, as indicated by surviving darker color roots (Fig 4; B and C). Exposure for 9 days or longer did damage all submerged roots. Nevertheless, after termination of shallow water table treatment and excess water had been drained, the roots successfully regrew (Fig 4; D and E). Exposure for 24 days killed all roots below water table (Fig 4; F). Clearly, roots of common bean were susceptible to shallow water table but the crop was able to recover after termination of the stress by regenerating new roots.

Root dry weight was affected by shallow water table (Fig 5). Current results showed that root dry weight of common bean decreased only if they were continuously exposed to shallow water table for 24 days. Interestingly, exposure to shallow water table for 12 days or less increased root dry weight of about 19.97 to 47.95 percent compared to that of untreated control, albeit variability among individual plant within each treatment was considerably high.

Subsidence of growing substrate in polybag during experiment was inevitable. Descending surface of the media resulted in shallower water table. Adding substrate material into the polybags would not solve the problem since existing position of root system is the one condition that matters, not the elevated surface of growing substrate. The descending position of substrate surface varied among polybags observed in this study. Therefore, it also instigated variation in depth of water table. The variation was from 11.5 to $15.8 \mathrm{~cm}$. However, the dissimilarity of water table depths within this range did not significantly affect RLER (Fig 6).

\section{Effect on yield}

Exposing the bean plants to shallow water table condition was started at early flowering stage. Limiting aerobic rhizosphere layer with application of shallow water table affected root functioning on supporting shoot growth and yield (Fig 7). Short (3 days) water table treatment decreased common bean yield, but the longer treatments did not. In fact, the bean yields showed tendency to increase as shallow water table exposures lengthened up to 24 days. Higher yield of the plants exposed to longer shallow water table conditions was associated with higher substrate moisture content. During the same period of time, substrate moisture contents of all shorter term $(3,6,9$, and 12 days) treated plants were dropped to below 10 percent as soon as they entered their recovery periods (Fig 8).

Differences in common bean response was directly associated with number of pods per plant, not related to average of pod weight or length, with exception to length of pod in common bean exposed for 24 days. There was significant correlation between number of pods and yield (Fig. 9).

\section{Discussion}

As in most plant organs, leaf grows through cell division and then cell expansion. Transition from cell division to expansion controls organ growth and size. This process was regulated by molecular mechanism (Nelissen et al., 2012). 


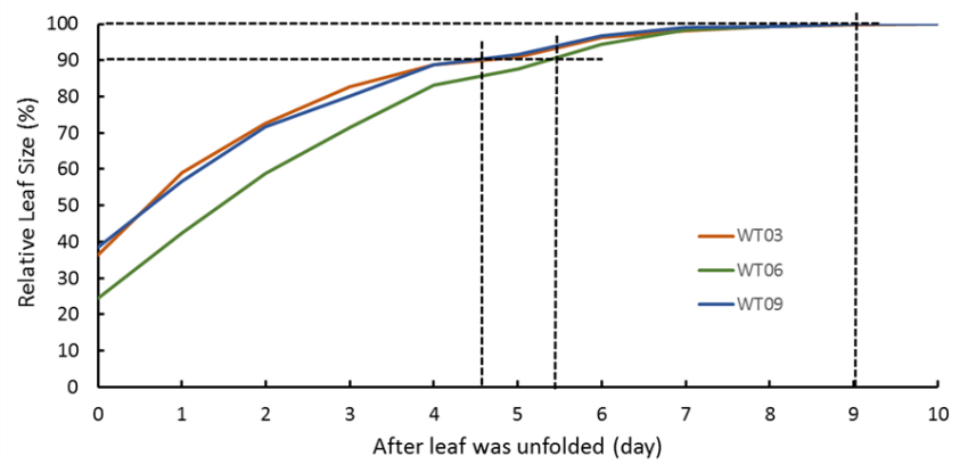

Fig 1. Asymptotical pattern of leaf growth in common bean (Phaseolus vulgaris). Measurement was done during vegetative growth stage, from 14 to 24 DAP. Despite leaf size differences at time of unfolding, the leaves reached their full size after 9 days or earlier.

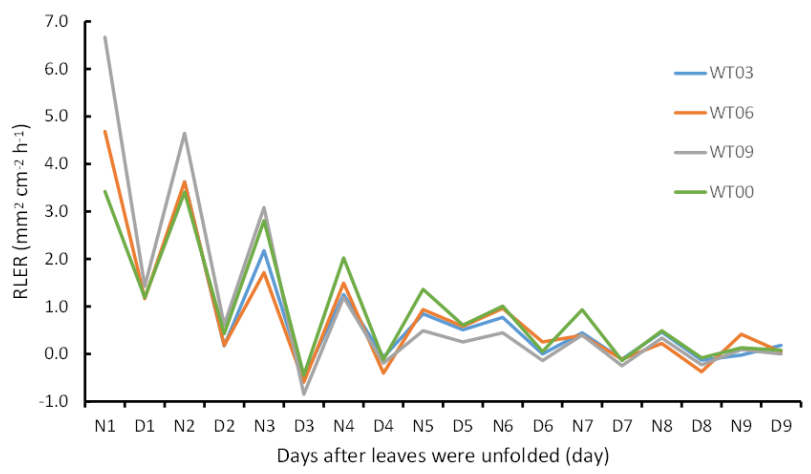

Fig 2. Dynamics of nocturnal (N) and diurnal (D) relative leaf expansion rate (RLER) in common bean (Phaseolus vulgaris) during 9-day period exposed to shallow water table.

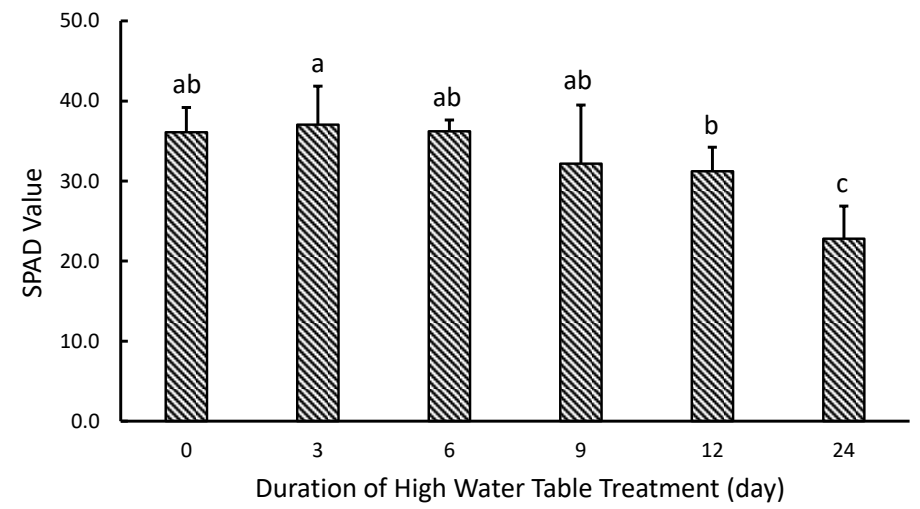

Fig 3. Mean and standard deviation of SPAD value as affected by duration of shallow water table treatments in common bean (Phaseolus vulgaris). Bars with similar small letters are not significantly different at LSD .05 .

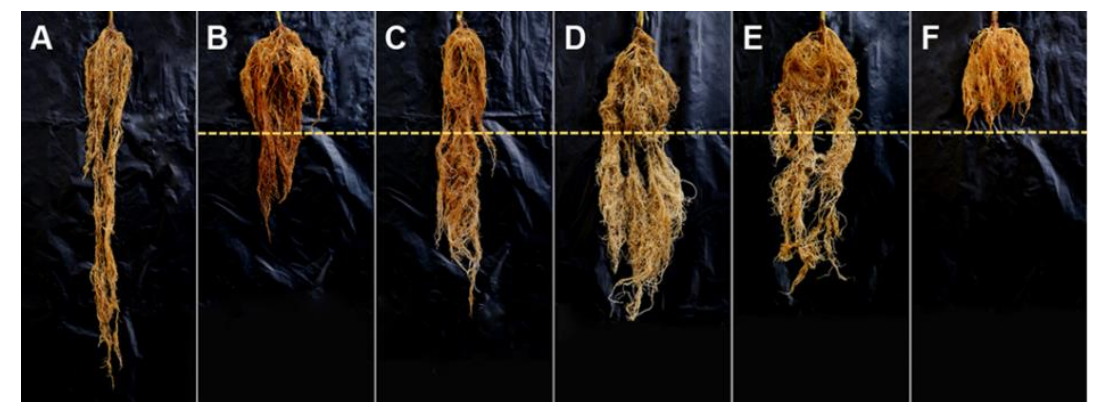

Fig 4. Roots of common bean (Phaseolus vulgaris) exposed to shallow water table for 0 day (A), 3 days (B), 6 days (C), 9 days (D), 12 days (E) and 24 days (F). Horizontal broken line is the average depth of water table at $13.5 \mathrm{~cm}$ below surface of growing substrate. After termination of the treatments, there were some new roots (whitish color) grew at the previously water saturated zone in $C, D$, and $E$ treatments. 


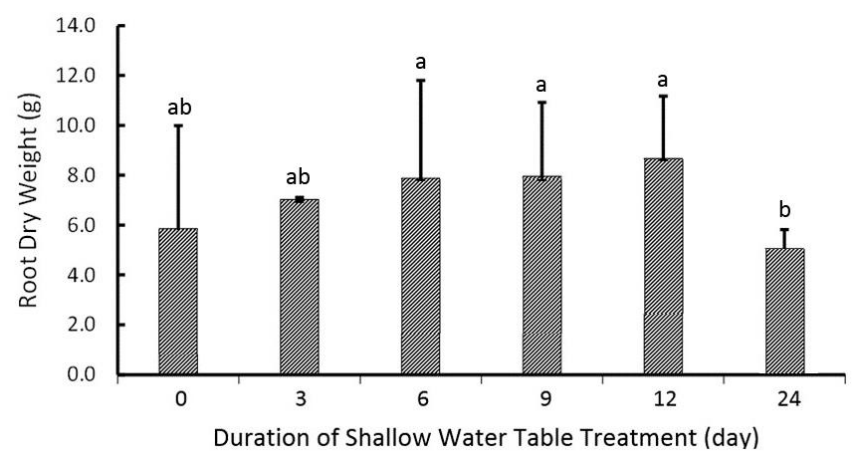

Fig 5. Root dry weight in Phaseolus vulgaris exposed to shallow water table up to 24 days. Bars with similar small letters are not significantly different at $L S D_{.05}$.

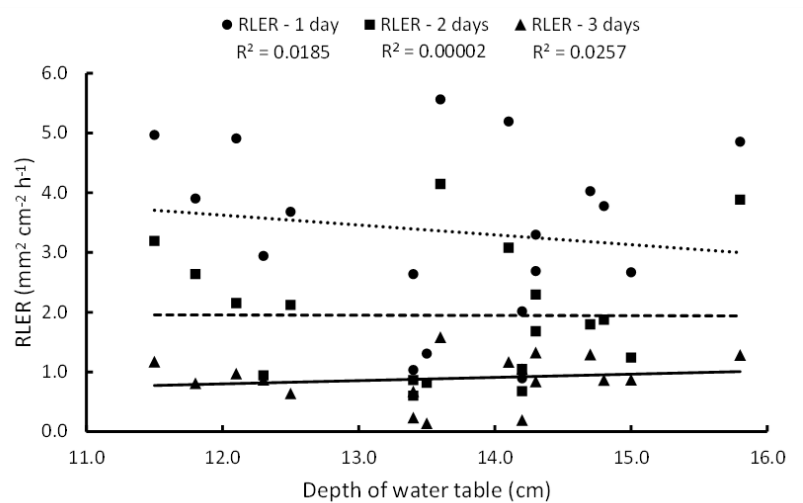

Fig 6. Correlation between depth of water table and RLER in common bean (Phaseolus vulgaris) after exposed to the treatment for 1,2 , and 3 days.
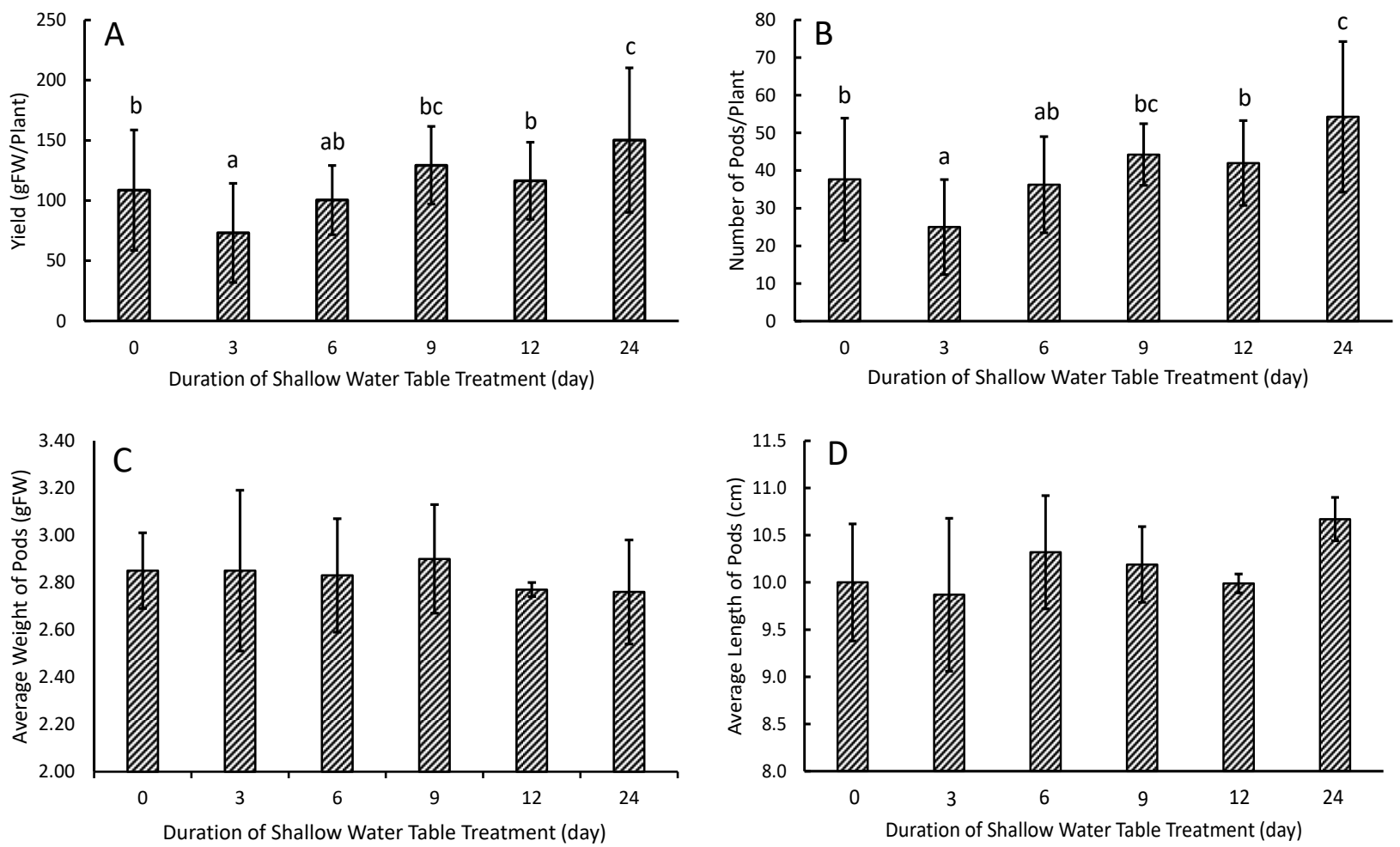

Fig 7. Yield (A), number of pods (B), average pod weight (C), and average pod length (D) in common bean (Phaseolus vulgaris) exposed to different durations of shallow water table. Similar small letters above bars at panel $A$ and $B$ indicated no significant different at $p<0.10$. No small letter above bars at panel $C$ and $D$ indicated shallow water table did not significantly affect average pod weight (C) and length (D). 


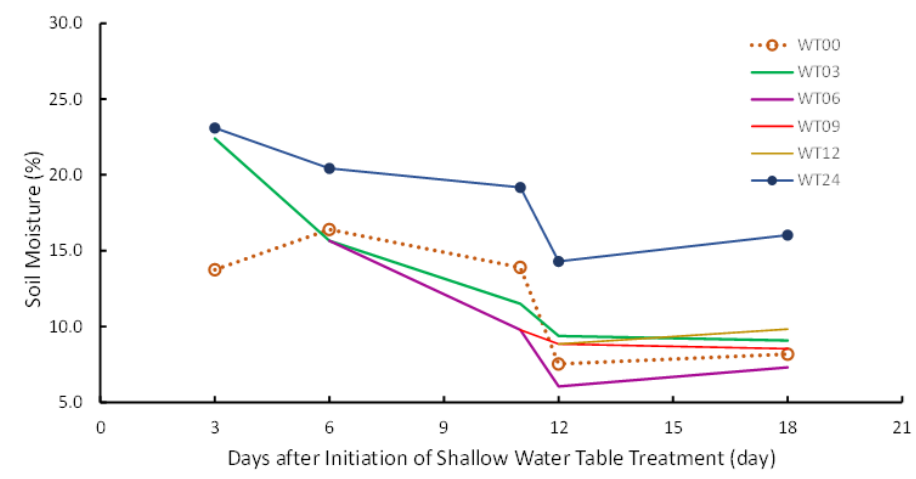

Fig 8. Moisture at depth of $5 \mathrm{~cm}$ among growing media treated with shallow water table compared to that of untreated control (dotted line).

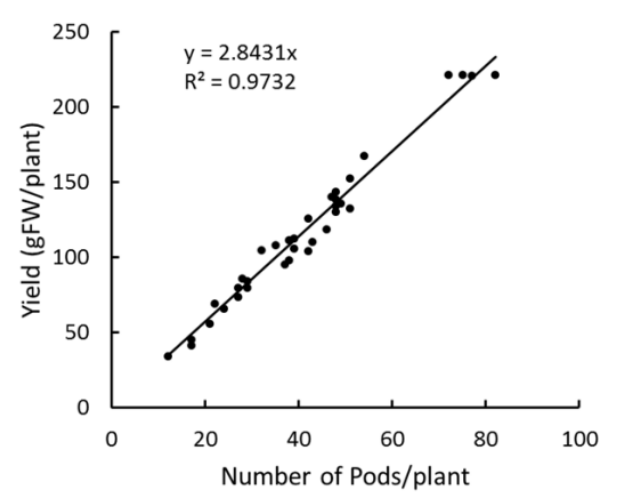

Fig 9. Correlation between number of pods and yield in common bean (Phaseolus vulgaris).

2012). In dicot plants, leaf growth was regulated by cell division ceasing earlier at the tip and gradually continuing to the base of the leaf (Nelissen et al., 2016). Common bean is a dicot plant. Leaf growth in most of plants is terminated within 2 weeks. Common bean used in our study indicated that their leaves have reached its full size in about 9 days (Fig 1).

Szymanski (2014) reported that in dicot leaves, the spatial and temporal patterns of cell division and expansion are heterogeneous. There were polarized growths at molecular (Nelissen et al., 2012), individual cell, cell cluster, and leaf morphology level (Szymanski, 2014). This polarized growth even more pronounced under stressful conditions as indicated by high standard deviation among plants exposed to stress condition.

In common bean exposed to shallow water table in our study, a higher RLER was observed at early leaf development. It also revealed that RLER was much higher at night than during daytime (Fig 2). Reymond et al. (2003) pointed out that leaf expansion in corn was correlated with leaf water potential. Similarly, Yang et al. (2009) also proved that decrease in corn leaf expansion rate occurred as leaf water potential decrease. Leaf water potential is directly related to leaf water content which are strongly influenced by soil moisture content. In our study, soil moisture content was 5 to 8 percent higher in growing substrate treated with shallow water table than that in untreated substrate (Fig 8). Albeit it was expected that higher water table would increase soil moisture content at upper $5-\mathrm{cm}$ layer of growing substrate; nonetheless, the water table varied from
11.5 to $15.8 \mathrm{~cm}$ depth did not significantly affect RLER (Fig 6). The SPAD value of common bean exposed to 24 days of shallow water table was significantly lower than that of untreated control. However, there were no significant differences between the untreated control and plants treated with shallow water table for up to 12 days (Fig 3). Lower SPAD value has been proven to be associated with low chlorophyll and nitrogen contents (Yang et al., 2014; Yuan et al., 2016; Zheng et al., 2015). A visual approach was used for comparing vertical root distribution among common bean plants exposed to different durations of shallow water table condition (Fig 4). All parts of existing roots trapped in water-saturated substrate layer beneath water table died within 9 days (WT09). Inability of roots to survive under water saturated condition was also reported by Ferreira et al. (2017) who found that potato roots were dead up to $6 \mathrm{~cm}$ above water table if the water table was set at $36 \mathrm{~cm}$ below soil surface. New roots, however, were developed soon after the shallow water table treatment was terminated.

Ability of roots to recover in common bean during longer duration of shallow water table conditions was associated with: (1) ability of common bean to enhance branching of their roots within aerobic upper layer of the rhizosphere which followed by root regrowth after termination of the shallow water table treatments (Fig 4); and (2) stable and optimal moisture content at around 20 percent at growing substrate above water table with average water table depth of $13.5 \mathrm{~cm}$. Ability of plants to survive during and/or after being exposed to excess water conditions was associated 
with their ability to develop adventitious roots and/or aerenchyma spaces (Hossain and Uddin, 2011; Júnior et al., 2015). Furthermore, Habibzadeh et al. (2013) found that foliar application of nitrogen compounds helped plants to recover after experiencing unfavorable conditions. Despite the highest yield, common bean treated with shallow water table for 24 days exhibited low SPAD value (Fig 3), thus low chlorophyll and nitrogen contents, at the end of harvesting period. It is arguable that the low SPAD value might or might not be due to direct effect of the shallow water treatment, since it might also be due to over exploitation of leaf nitrogen for supporting their pod development. Surely, this argument requires further research to resolve it. Besides affecting yield, the shallow water treatments also affected number of pods per plant. However, averaged weight and length of pod were not affected (Fig 7). Moreover, it was found that number of pods was significantly correlated with the yield of common bean used in this study (Fig 9), meaning that differences in yield was driven by number of pods/plant, not due to the weight or size of pods. Similar results were reported by Assefa et al. (2015) and Sofi et al. (2017). Both research teams found that among yield components, number of pods contributed the most in yield reduction in common bean.

Ability of common bean to tolerate shallow water table condition has been proven. Therefore, it is reasonable to recommend cultivation of this vegetable crop at shallow water table zone within riparian wetland ecosystem. Common bean could also be grown after rice harvesting, at time rice fields had gradually dried out. Growing additional crops to a rarely utilized area or during rice off season will increase cropping intensity by local farmers and productivity of the riparian wetland.

\section{Materials and Methods}

\section{Plant materials}

Plant material used was common bean (Phaseolus vulgaris L.) variety of PV072. This is a bushy type bean with semideterminate growing behavior. Seeds were soaked in tap water for 3 hours prior to direct planting. The primary shoot tip (terminal bud) was pinched to remove apical meristem for promoting development of lateral branches after the third trifoliate leaf was fully developed,

\section{Location and time of the research conduction}

This research was conducted at Jakabaring $\left(104^{\circ} 46^{\prime} 44^{\prime \prime} \mathrm{E}\right.$; $3^{\circ} 01^{\prime} 35^{\prime \prime}$ S), Palembang, South Sumatra, Indonesia. It is only 3 degrees south of the equatorial line. Length of day and night period was almost constant at about 12 hours all around the year. This information is worth of mentioning since we measured RLER at night period (nocturnal) and day period (diurnal). The research was started in November 2016 and completed in February 2017, during rainy season. The season in which shallow water table problem was commonly occurs at riparian wetlands in South Sumatra.

\section{Growing substrate used}

Growing substrate used was a mix of soil, goat manure, and rice husk at ratio of 1:1:1 based on volume. The media was filled into black polyethylene bags (polybags) up to $30 \mathrm{~cm}$ height. Filled polybag has a diameter of $25 \mathrm{~cm}$. Drainage holes were made at circular side and bottom of the polybags. Two seeds were planted in each polybag but only one seedling was kept after 7 days after planting (DAP). Fertilizers applied were $0.9 \mathrm{~g} \mathrm{NH}_{4}^{+}, 0.6 \mathrm{~g} \mathrm{NO}_{3}^{-}, 1.0 \mathrm{~g} \mathrm{P}_{2} \mathrm{O}_{5}$, and $1.5 \mathrm{~g} \mathrm{~K}_{2} \mathrm{O}$ per polybag at $10 \mathrm{DAP}$. The fertilizer application was repeated using the same dose at 1 day after shallow water table treatment was terminated.

\section{Water table definition and treatment set-up}

Water table is a border line between water saturated (lack of oxygen) zone and aerobic (oxygen available) zone in growing substrate. Shallow water table condition occurs if the water table is close to surface of growing substrate. Due to gravitation, position of the water saturated zone is always below the aerobic zone in growing substrate.

The shallow water table treatments were commenced at 29 DAP (at early flowering stage). Seventy two relatively homogenous plants were selected from stock nursery. Treatments were consisted of six durations of shallow water table condition, i.e. 0 days (WT00 as control), 3 days (WT03), 6 days (WT06), 9 days (WT09), 12 days (WT12), and 24 days (WT24). Four plants were randomly selected from each group to represent non-treated control (WTO0). Twenty plants were placed into each of three $2 \times 4$ meter experimental pool. The 21 plants in each pool were arranged in 3 rows, each row was consisted of 7 plants.

All of the experimental pools were filled with water to a depth of $10 \mathrm{~cm}$. Since the pools used were outdoor pools, the control valves for maintaining water depth at $10 \mathrm{~cm}$ were kept open such that excess rain water was freely spilled out of the pools through the open valves. At 3, 6, 9, 12 , and 24 days after commencement of shallow water table treatments, 4 plants in each pools or 12 plants in total were randomly taken out for terminating each treatments, i.e. WT03, WT06, WT09, WT12, and WT24. At end of each treatment, the polybags were taken out of the pool and were placed back to its same position prior to treatment application.

\section{Traits measured and data collection}

Non-destructive leaf area estimation was done using model developed by Lakitan et al. (2017). Prior to Relative Leaf Expansion Rate (RLER) measurements, time span for leaf of common bean to reach its maximum size was studied in order to differentiate between decreased in RLER due to stress induced by shallow water table treatment and due to natural cause. RLER was calculated based on leaf area measured twice per day, i.e., between 6.00 to 6.30 a.m. and between 5.30 to 6.00 p.m. Therefore, nocturnal RLER (during night time) can be differentiated from diurnal RLER (during daytime).

Subsidence of growing substrate in polybags after one month in used was unavoidable and it created variability in position of the media surface; thus, also differed depth of water table which was measured based on difference between media surface and water level. Effects of this unintended variability in depth of water table on RLER were evaluated by examining correlation between the depth of water table and RLER. SPAD values measured at 53 DAP (at 
end of the 24-day treatment), using chlorophyll meter (Konica-Minolta SPAD-502Plus). The SPAD value were commonly used and reliable in estimating leaf chlorophyll and nitrogen contents (Rodriguez and Miller, 2000; Lakitan et al., 2018). Three leaves were measured and averaged for each sample plant for all treatments and all replications.

Roots are the most directly affected by shallow water table condition. Morphology of common bean roots after exposure to different duration of shallow water table treatments were studied, visually and quantitatively. Soil moisture content was monitored during shallow water table treatment (using soil moisture meter Lutron PMS-714). Quantitative analysis of the roots followed the same statistical procedure applied to SPAD, yield, and yield components. Common bean was harvested when pods already developed to its optimum size but still young, indicated by slight swelling at position of seeds. Yield was measured as cumulative pod fresh weight per plant throughout harvesting period. Measured yield components included total number of pods per plant, average fresh weight of pod, and average length of pod. Correlations between yield and each of its components were performed for identifying which yield component significantly contributed to the economic yield, i.e. marketable young pods.

\section{Data analysis}

Treatments and replications were laid out based on Randomized Block Design. Analysis of variance was conducted for detecting significant effect of shallow water table treatments on variables measured. If treatment effect on any variables was at least significant at $p<0.05$, differences amongst treatments in those variables were further tested using the Least Significant Difference (LSD $\left.{ }_{.05}\right)$. For specific purposes, mean comparisons between a pair of independent treatments were also conducted. The zerointercept linear regression was used for evaluating correlation between two related variables.

\section{Conclusion}

Shallow water table condition at depth around $13.5 \mathrm{~cm}$ below surface of growing substrate for up to 12 days can be tolerated by common bean (Phaseolus vulgaris) as indicated by no significant reduction of pod yield, number of pods/plant, average pod weight, pod size, root dry weight, SPAD value, and RLER. Pod yield under shallow water table condition was more regulated by number of pods per plant. Surprisingly, pod yield and number of pods/plant were significantly higher if common bean plants were treated with shallow water table for 24 days, albeit their root growth were limited within aerobic upper layer of growing substrate during treatment. Oxygen availability and higher moisture at upper rhizosphere during shallow water table condition seems to contribute to the higher yield. However, further study is needed to prove this proposition.

\section{Acknowledgments}

This work was supported by the Program Penelitian Unggulan Profesi 2016-2017 Universitas Sriwijaya (SK No.0242/UN9/KP/2016). We would like to express our appreciation to the editor-in-chief and editors of this journal for their superb helps and guidance; and also to unanimous reviewers for their corrections and suggestions for improving quality of this article.

\section{References}

Ashraf MA, Ahmad MSA, Ashraf M, Al-Qurainy F, Ashraf MY (2011) Alleviation of waterlogging stress in upland cotton (Gossypium hirsutum L.) by exogenous application of potassium in soil and as a foliar spray. Crop Pasture Sci. 62:25-38.

Assefa T, Wu J, Beebe SE, Rao IM, Marcomin D, Claude RJ (2015) Improving adaptation to drought stress in small red common bean: phenotypic differences and predicted genotypic effects on grain yield, yield components and harvest index. Euphytica. 203:477-489.

Bajgain R, Kawasaki Y, Akamatsu Y, Tanaka Y, Kawamura H, Katsura K, Shiraiwa T (2015) Biomass production and yield of soybean grown under converted paddy fields with excess water during the early growth stage. Field Crop Res. 180:221-227.

Colmer TD, Greenway H (2011) Ion transport in seminal and adventitious roots of cereals during $\mathrm{O} 2$ deficiency. J Exp Bot. 62:39-57.

Ferreira CJB, Zotarelli L, Tormena CA, Rens LR, Rowland DL (2017) Effects of water table management on least limiting water range and potato root growth. Agr Water Manage. 186:1-11.

Habibzadeh F, Sorooshzadeh A, Pirdashti H, ModarresSanavy SAM (2013) Alleviation of waterlogging damage by foliar application of nitrogen compounds and tricyclazole in canola. Aust J Crop Sci. 7(3):401-406.

Hossain MA, Uddin SN (2011) Mechanisms of waterlogging tolerance in wheat: Morphological and metabolic adaptations under hypoxia or anoxia. Aust J Crop Sci. 5(9): 1094-1101.

Irfan M, Hayat S, Hayat Q, Afroz S, Ahmad A (2010) Physiological and biochemical changes in plants under waterlogging. Protoplasma. 241:3-17.

Júnior WVA, Filho BGS, Lobato AKS, Tan DKY, Neto CFO, Pereira ACC, Cunha RLM, Costa RCL, Kikuchi TYS, Okumura RS (2015) Negative interference on growth and morphoanatomical modifications in young Parkia gigantocarpa plants under waterlogging. Aust J Crop Sci. 9(6): 523-531

Lakitan B, Widuri LI, Meihana M (2017) Simplifying procedure for a non-destructive, inexpensive, yet accurate leaf area estimation in common bean (Phaseolus vulgaris). J Appl Hortic. 19:15-21.

Lakitan B, Alberto A, Lindiana L, Kartika K, Herlinda S, Kurnianingsih A (2018) The benefits of biochar on rice growth and yield in tropical riparian wetland, South Sumatera, Indonesia. Chiang Mai Univ J Nat Sci. 17(2):111126

Najeeb U, Tan DKY, Michael P. Bange, MP (2016) Cotton growth and yield dynamics across canopy layers in response to soil waterlogging. Aust J Crop Sci. 10(8):11701181.

Nelissen H, Gonzalez N, Inzé D (2016) Leaf growth in dicots and monocots: so different yet so alike. Curr Opin Plant Biol. 33:72-76. 
Nelissen H, Rymen B, Jikumaru $Y$, Demuynck K, Van Lijsebettens M, Kamiya Y, Inzé D, Beemster GTS (2012) A Local Maximum in Gibberellin Levels Regulates Maize Leaf Growth by Spatial Control of Cell Division. Curr Biol. 22:1183-1187.

Reymond M, Muller B, Leonardi A, Charcosset A, Tardieu F (2003) Combining quantitative trait loci analysis and an ecophysiological model to analyze the genetic variability of the responses of maize leaf growth to temperature and water deficit. Plant Physiol. 131:664-675.

Rodriguez IR, Miller GL (2000) Using a chlorophyll meter to determine the chlorophyll concentration, nitrogen concentration, and visual quality of St. Augustine grass. HortScience 35:751-754.

Sauter M (2013) Root responses to flooding. Curr Opin Plant Biol. 16:282-286.

Sofi PA, Rehman K, Bhat MA (2017) Relative water content, membrane stability index and $D A B$ assay in relation to reduction in yield components and resource remobilization under water stress in common bean (Phaseolus vulgaris L.). SKUAST J Res. 19:133-142.
Soppe RW, Ayars JE (2002) Crop water use by safflower in weighing lysimeters. Agr Water Manage. 60:59-71.

Yang H, Yang J, Lv Y, He J (2014) SPAD Values and Nitrogen Nutrition Index for the Evaluation of Rice Nitrogen Status. Plant Prod. Sci. 17:81-92.

Yang Y, Timlin DJ, Fleisher DH, Kim SH, Quebedeaux B, Reddy VR (2009) Simulating leaf area of corn plants at contrasting water status. Agr Forest Meteorol. 149:1161-1167.

Yuan Z, Ata-Ul-Karim ST, Cao Q, Lu Z, Cao W, Zhu Y, Liu X (2016) Indicators for diagnosing nitrogen status of rice based on chlorophyll meter readings. Field Crop Res. 185:12-20.

Zheng HL, Liu YC, Qin YL, Chen Y, Fan MS (2015) Establishing dynamic thresholds for potato nitrogen status diagnosis with the SPAD chlorophyll meter. J Integr Agr. 14:190-195.

Zhou J, Qi A, Zhang Y, Wan S, Qin P (2012) Adventitious root growth and relative physiological responses to waterlogging in the seedlings of seashore mallow (Kosteletzkya virginica), a biodiesel plant. Aust J Crop Sci. 6(1): 73-80. 